\title{
20ß-hydroxysteroid dehydrogenase and CYP19A1 are differentially expressed during maturation in Atlantic cod (Gadus morhua)
}

\author{
C Mittelholzer, E Andersson ${ }^{1}$, D Consten, T Hirai $^{2}$, Y Nagahama ${ }^{3}$ and B Norberg \\ Institute of Marine Research, Austevoll Research Station, N-5392 Storebø, Norway \\ ${ }^{1}$ Institute of Marine Research, N-5817 Bergen, Norway \\ ${ }^{2}$ Department of Biosciences, Teikyo University of Science and Technology, Uenohara, Japan \\ ${ }^{3}$ Laboratory of Reproductive Biology, National Institute for Basic Biology, 444-8585 Okazaki, Japan \\ (Correspondence should be addressed to C Mittelholzer who is now at University of Basel, Klingelbergstrasse 60, $\mathrm{CH}-4056$ Basel, Switzerland; \\ Email: christian.mittelholzer@unibas.ch) \\ D Consten is now at St Elisabeth Hospital, PO Box 90151, 5000 LC Tilburg, The Netherlands
}

\begin{abstract}
In order to better quantify the molecular mechanisms regulating final oocyte maturation and spawning, complete coding sequences with partially or fully untranslated regions for the steroidogenic enzymes, cytochrome P450 aromatase and 20ßhydroxysteroid dehydrogenase, were cloned from ovaries of Atlantic cod (Gadus morhua). The nucleotide and amino acid sequences showed high homologies with the corresponding sequences of other fish species, and conserved features important for functionality were identified in both predicted proteins. The sequences of the corresponding genomic loci were also determined, allowing the design of mRNA-specific quantitative PCR assays. As a reference gene for the real-time RT-PCR assays, eukaryotic elongation factor $1 \alpha$ was chosen, and the mRNA as well as the genomic sequence was determined. In addition, a real-time quantitative PCR assay for the $18 \mathrm{~S}$ rRNA was adapted to be used in cod. Analysis of immature and maturing female cod from July to January respectively showed that the enzyme genes showed the expected quantitative changes associated with physiological regulation. However, mRNA for eukaryotic elongation factor $1 \alpha$, and to a lesser extent even 18S rRNA, showed variable expression in these samples as well. To find accurate standards for real-time PCR in such a dynamic organ as the cod ovary is not an easy task, and several possible solutions are discussed.
\end{abstract}

Journal of Molecular Endocrinology (2007) 39, 319-328

\section{Introduction}

In teleosts, like in other vertebrates, puberty and reproduction are controlled by the brain-pituitarygonadal axis. The gonadotropic hormones, folliclestimulating hormone (FSH) and luteinizing hormone (LH), secreted from the pituitary under control of gonadotropin-releasing hormones (GnRHs) released by the brain, play a central role. They act on somatic cells in the gonads, and thereby regulate gonadal biosynthesis of steroid hormones. During final oocyte maturation, a shift in steroidogenesis occurs in ovarian follicles, mediated by changes in gene expression of steroidogenic enzymes like ovarian $\mathrm{P} 450$ aromatase (encoded by the cyp19a1 gene)

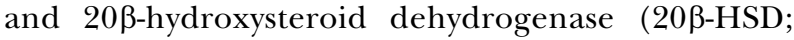
Senthilkumaran et al. 2004). This is concomitant with a switch from predominantly FSH toward higher levels of $\mathrm{LH}$, and leads to the production of primarily maturationinducing steroid (MIS), instead of conversion of testosterone into estradiol $\left(\mathrm{E}_{2}\right)$, in the ovarian follicles. Whereas MIS is produced by the action of $20 \beta-\mathrm{HSD}$, the conversion of androgens (C19) to estrogens (C18) is catalyzed by an enzyme complex containing P450 aromatase, product of the cyp19 gene, and a flavoprotein NADPH-cytochrome P450 reductase (Simpson et al. 1994). The enzymatic activity of $\mathrm{P} 450$ arom is thought to be the rate-limiting step in estrogen biosynthesis (Simpson et al. 1994) and changes in P450arom enzyme activity or expression of cyp19genes have been shown to be major regulators of the gonadal production of $\mathrm{E}_{2}$ during reproduction and development (Chang et al. 1997). Numerous reports have therefore focused on the identification and characterization of cyp19a1 genes in fish, but studies in periodic spawners, like Atlantic cod, are scarce (Van Nes et al. 2005), and to our knowledge none is dealing with events during final oocyte maturation and spawning.

Sequences for the carbonyl-reductase like 20ß-hsd gene are available only from a few teleost species (ayu, Tanaka et al. 2002; Japanese eel, Kazeto et al. unpublished; rainbow trout, Guan et al. 1999; Nile tilapia, Senthilkumaran et al. 2002; and zebrafish, Wang \& Ge 2002), despite high similarity scores that should facilitate 
cloning of homologous sequences from other species. The protein encoded by this gene belongs to the shortchain steroid dehydrogenase/reductase superfamily (Jörnvall et al. 1995) and catalyzes the NADPH reduction of carbonyl compounds and steroids. The gene is broadly expressed in a variety of fish tissues (Guan et al. 1999, Senthilkumaran et al. 2002, Wang \& Ge 2002), and it is evident that the 20ß-HSD represents the key enzyme for the production of MIS (Tanaka et al. 2002).

In Atlantic cod (Gadus morhua L.) in Norwegian waters, vitellogenesis normally starts in October, while the peak in spawning activity occurs in February-March (Kjesbu 1994). Cod eggs are small, and vitellogenesis is a rapid process, which takes place in the months immediately prior to spawning, as well as during the spawning period (Kjesbu et al. 1991, 1996). The Atlantic cod is a periodic spawner, and each female can release 15-20 batches of pelagic eggs at 50-100-h intervals, during a period of 3-4 weeks (Kjesbu 1989). The endocrine regulation of the recruitment of oocyte clusters into final maturation is poorly understood in periodic spawners, and the MIS has not been conclusively identified in cod.

A stable and predictable supply of gametes of defined quality on one side and the prevention of precocious maturation on the other side are crucial steps in the successful farming of Atlantic cod. Optimal use of production facilities requires year-round access to highquality juveniles, which can be achieved only by the manipulation of the time of spawning. On the other hand, unwanted early sexual maturation or puberty during on-growth will lead to economic losses due to decreased meat quantity and quality as well as increased susceptibility of the fish to diseases. To better quantify the events during puberty, final oocyte maturation, and spawning in Atlantic cod, we determined both mRNA and genomic sequences of two key genes, cyp19a1 and 20ß-hsd, and established mRNA-specific quantitative real-time PCR assays.

\section{Materials and methods}

\section{Animals and sample collection}

Larvae of coastal cod, hatched in spring 2000, were raised in a seawater pond (Parisvatnet) situated outside Bergen, Norway (Øiestad et al. 1985), and transferred to net pens at the same location in late autumn. The fish were transported to the Institute of Marine Research, Austevoll Research station $\left(60^{\circ} \mathrm{N}\right)$ in July 2001 and maintained in a $12 \times 12 \times 5 \mathrm{~m}$ sea cage, at natural photoperiod and temperature. The temperature fluctuated through the year, between $5{ }^{\circ} \mathrm{C}$ (February-March) and $20^{\circ} \mathrm{C}$ (August). At sampling, the fish were stunned by a blow to the head in accordance with Norwegian regulations for killing fish, and individual tissue samples were collected. The samples were either snap-frozen in liquid nitrogen before storage at $-80{ }^{\circ} \mathrm{C}$, or stored in RNAlater (Ambion/Applied Biosystems, Oslo, Norway) at $4{ }^{\circ} \mathrm{C}$ for up to 1 month.

\section{Cloning and sequence of Atlantic cod cyp19a1 and 20ß-hsd cDNA}

Samples stored at $-80^{\circ} \mathrm{C}$ were cut into small pieces on dry ice before immediate transfer to cold Tri Reagent (SigmaAldrich) or Isogen (Nippongene, Tokyo, Japan), in order to preserve RNA quality. Samples stored in RNAlater were blotted with a wipe to remove excess liquid. Total RNA was extracted by the acid phenol-guanidinium thiocyanate method from 50-100 mg ovarian tissue, and polyA+-RNA was isolated using Dynabeads (Dynal, Oslo, Norway) according to the manufacturer's instructions. Random primed cDNA was synthesized with Superscript II (Invitrogen), and PCR was performed using degenerate primers designed for the amplification of a large part of the coding region of cyp19a1 (Gen et al. 2001). The two resulting PCR products were cloned into a pGEM-Teasy (Promega) and a pCR II-TOPO vector (Invitrogen) respectively, and cycle sequenced using an automated ABI PRISM Model 377 machine, based on the incorporation of fluorescently labeled dideoxynucleotide terminators.

Based on the sequences of the fragments, $5^{\prime}$ - and $3^{\prime}$-rapid amplification of cDNA ends (RACE) primers were designed and applied to cDNA synthesized with the Marathon kit (ClonTech), according to the manufacturer's instructions. The resulting fragments were cloned into a pCR II-TOPO or pCR4-TOPO vector (Invitrogen) and cycle sequenced as described previously. Consensus sequences from at least two clones (in case of ambiguities at least three clones were sequenced) were assembled using the MegAlign software of the Lasergene package (DNASTAR, Madison, WI, USA). Primer sequences and detailed amplification procedures are available from the authors on request.

\section{Cloning and sequence of Atlantic cod eef1 $\alpha$ cDNA}

Based on an alignment of 11 fish eefl $\alpha$ sequences (AF321836, salmon; AF498320, trout; AF485331, carp; AY422992, zebrafish; AB056104, goldfish; AB013606, medaka; AB032900, yellowtail; AB075952, tilapia; AF467776, turbot; AF184170, gilthead seabream; AY190693, red seabream), primers were designed to encompass a region targeted by a published mRNAspecific salmon louse assay (Frost \& Nilsen 2003). Amplification of both mRNA, from an ovarian cDNA library (Goetz et al. 2006), and genomic DNA (a kind gift from Dr Geir Dahle, Institute of Marine Research, Bergen, Norway) resulted in two fragments of different sizes, and both were cloned into a pCR4-TOPO vector before cycle sequencing as described previously. This allowed the 
design of an mRNA-specific set of qPCR primers and probes, as well as $5^{\prime}$ - and $3^{\prime}$-RACE primers. The latter were applied to cDNA synthesized with the SMART kit (ClonTech) according to the manufacturer's instructions. The resulting fragments were cloned into a pCR II-TOPO or pCR4-TOPO vector (Invitrogen) and cycle sequenced as described previously. Consensus sequences from at least two clones (in the case of ambiguities at least three clones were sequenced) were assembled using the MegAlign software of the Lasergene package (DNASTAR). Primer sequences and detailed amplification procedures are available from the authors on request.

\section{Determination of genomic sequences}

Primers encompassing the whole coding sequences were applied to genomic DNA, either kindly provided by Dr Geir Dahle, Institute of Marine Research, Bergen, Norway or extracted from ovary and liver respectively by a modified proteinase $\mathrm{K}$ (PK) method. Briefly, $10-20 \mathrm{mg}$ tissue was added to $600 \mu \mathrm{l}$ lysis buffer (10 mM Tris-HCl (pH 8.0); $1 \mathrm{mM}$ EDTA (pH 8.0); $0 \cdot 1 \%$ SDS) on ice before $60 \mu \mathrm{g}$ PK (Promega) were added. After overnight incubation at $55^{\circ} \mathrm{C}$, the samples were cooled to room temperature before the addition of $12 \mu \mathrm{g}$ DNase-free RNase (Qiagen) and a further incubation for $30 \mathrm{~min}$ at $37^{\circ} \mathrm{C}$. After cooling the samples to room temperature, $200 \mu$ l potassium acetate solution (60 ml $5 \mathrm{M} \mathrm{KOAc,} 11.5 \mathrm{ml}$ glacial acetic acid, and $28.5 \mathrm{ml} \mathrm{H}_{2} \mathrm{O}$ ) was added, and the samples vigorously mixed and centrifuged for $3 \mathrm{~min}$ at $4{ }^{\circ} \mathrm{C}$ at a maximum speed. Genomic DNA contained in the supernatant was recovered by isopropanol precipitation, washed with $70 \%$ ethanol, and resuspended in $100 \mu \mathrm{l}$ TE buffer. The resulting fragments for all three genes were cloned into a pCR4-TOPO vector (Invitrogen) and cycle sequenced as described previously. Due to the presence of large introns in the 20ß-hsd sequence, this gene was amplified in two overlapping fragments. Consensus sequences from at least two clones (in the case of ambiguities at least three clones were sequenced) were assembled using the MegAlign software of the Lasergene package (DNASTAR). Primer sequences and detailed amplification procedures are available from the authors on request.

\section{Quantitative real-time PCR}

Primers and TaqMan fluorogenic probes specific for Atlantic cod 20ß-hsd, cyp19a1, and for the endogenous control eef1 $\alpha$ were designed with Primer express software (Applied Biosystems), according to the manufacturer's guidelines. Probes for all three transcripts span exonexon boundaries in the mRNA sequence to prevent genomic DNA amplification. The primers complementary to two different but consecutive exons were subjected to an initial testing by running them in a conventional PCR on both cDNA and genomic DNA. Only primer pairs resulting in amplification products of different sizes due to the presence of an intron in the genomic DNA were further evaluated. A previously established assay for 18S rRNA of Atlantic salmon (Olsvik et al. 2005) was adapted for the use in Atlantic cod by changing the forward primer at three positions, based on $18 \mathrm{~S}$ rRNA sequences published in GenBank (accession numbers AF518205, U11437, and U76257). Primers were purchased from Invitrogen, and TaqMan MGB fluorogenic probes were purchased from Applied Biosystems (Table 1). Optimal primers and probe concentrations were then determined following Applied Biosystems guidelines, and serial dilutions of RNA and cDNA were tested to assess the quality of the real-time PCR. The PCR solution contained $900 \mathrm{nM}$ primers, $200 \mathrm{nM}$ TaqMan probe, $1 \times$ AmpliTaq Gold TaqMan Mix (Applied Biosystems) and $2 \mu \mathrm{l}$ template in a $25 \mu \mathrm{l}$ volume. The PCR profile was as follows: $50^{\circ} \mathrm{C}$ for $2 \mathrm{~min}, 40$ cycles at $95^{\circ} \mathrm{C}$ for $15 \mathrm{~s}$, and $60^{\circ} \mathrm{C}$ for $1 \mathrm{~min}$, followed by $72^{\circ} \mathrm{C}$ for $10 \mathrm{~min}$. Two or three PCR were performed for each sample and then averaged. Data were analyzed by Sequence Detector version 1.6.3 (Applied Biosystems).

\section{RNA extraction and reverse transcription}

Samples stored at $-80{ }^{\circ} \mathrm{C}$ were cut into small pieces on dry ice before immediate transfer to cold Tri Reagent (SigmaAldrich). After homogenization in a FastPrep microfuge tube containing Lysing Matrix D ceramic beads, total RNA was extracted by the acid phenol-guanidinium thiocyanate method followed by isopropanol precipitation or by purifying the RNA through a column (RiboPure kit, Ambion/Applied Biosystems), and quantified by spectrophotometry. Ten micrograms of RNA were DNase treated (TurboDNA-free, Ambion/Applied Biosystems) in $50 \mu \mathrm{l}$ volumes before the remaining RNA was again quantified by spectrophotometry. Random-primed cDNA was synthesized from exactly $500 \mathrm{ng}$ DNase-treated

Table 1 Primers and probes of the real-time quantitative RT-PCR

Sequence $\left(5^{\prime}-3^{\prime}\right)$

$\begin{array}{ll}\text { Name } & \\ \text { aceef1a_q1 } & \text { GCC CCT CCA GGA CGT CTA C } \\ \text { aceef1a } & \text { 6FAM-AGA TCG GCG GTA TTG-MGB } \\ \text { aceef1a_q2 } & \text { ACG GCC CAC GGG TAC TGT } \\ \text { ac20b-hsd_q1 } & \text { GGT CAA CAA TGC TGG GAT AGC } \\ \text { ac20b-hsd } & \text { 6FAM-TTT AAA GAA GCA GAC ACA ACA-MGB } \\ \text { ac20b-hsd_q2 } & \text { GCC TGC ACG GCA AAC G } \\ \text { accyp19a_q1 } & \text { ACA ACA ACA AGT ACG GCA GCA T } \\ \text { accyp19a } & \text { 6FAM-TTG CAC AGG GTC ATG G-MGB } \\ \text { accyp19a_q2 } & \text { GTA GAG GAG CTG CTG AGG ATG AG } \\ \text { ac18S_q1 } & \text { CCC TGT AAT TGG AAT GAG TGT ACT TT } \\ \text { ac18S } & \text { 6FAM-CAC CAG ACT TGC CCT CC-MGB } \\ \text { ac18S_q2 } & \text { ACG CTA TTG GAG CTG GAA TTA CC }\end{array}$

Journal of Molecular Endocrinology (2007) 39, 319-328 
RNA using a Reverse Transcription Core Kit (RT-RTCK-05, Eurogentec, Seraing, Belgium), and diluted 1:10 in nuclease-free $\mathrm{H}_{2} \mathrm{O}$ before use in the quantitative realtime PCR.

\section{Assessment of RNA quality}

For a choice of samples, RNA quantity and quality were also determined by capillary electrophoresis using the Lab on a Chip technique (Agilent 2100 BioAnalyzer, Santa Clara, CA, USA) in accordance with the manufacturer's instructions on the RNA 6000 Nano Labchip. The chip also generates a quantitative measure of the amount of RNA loaded.

\section{Results}

\section{CYP19A1 (P450 aromatase)}

A nearly full-length mRNA sequence of Atlantic cod cyp19a1 was determined by a RACE-based strategy. Initially, a central part of the mRNA was amplified from ovarian cDNAs by RT-PCR using degenerate primers (Gen et al. 2001). This allowed us to design specific $5^{\prime}$ - and $3^{\prime}$-RACE primers and subsequently to amplify $5^{\prime}$ and $3^{\prime}$ ends of the cyp 19a $1 \mathrm{mRNA}$. After compiling consensus sequences from the overlapping fragments, primers were designed to amplify the whole presumptive coding regions in one single piece. The inferred mRNA sequence for aromatase consisted of 1645 nucleotides, with a coding region of 1602 nucleotides and short $5^{\prime}$ untranslated region (UTR) of only 31 nucleotides. This was consistent across six independent $5^{\prime}$-RACE-clones. The $3^{\prime}$ UTR consisted of 12 unique nucleotides, followed by poly $(\mathrm{C})$ tracts of various length and GT repeats of even higher variability between the different $3^{\prime}$-RACE-clones. Since the focus of this work was not primarily to identify the longest possible UTRs, we did not further investigate the length and sequence of neither the $3^{\prime}$ nor the $5^{\prime}$ UTR. The deduced amino acid sequence consists of 533 residues and contains all the features characteristic of aromatases (Fig. 1). Similarity scores with other fish aromatases range from $56 \cdot 2$ to $68 \cdot 9 \%$.

The sequence of the corresponding genomic locus amplified using the primers designed to amplify the complete coding region, had a total length of 3882 nucleotides, and revealed the presence of nine exons and eight introns. The canonical sequence characteristics of vertebrate introns were completely conserved (Fig. 2), and the intron lengths ranged from 145 nucleotides for intron 5 to 591 nucleotides for intron 8 .

Based on the determined exon-exon boundaries, a TaqMan assay was developed for cyp19a1. In order to have an assay that is specific for the gonad form of aromatase, the near complete sequence of the cyp19a2 gene that codes for the neuronal form of aromatase was determined from brain tissue (data not shown). Comparison of this sequence with the cyp19a1 sequence revealed four mismatches in each primer and two mismatches in the probe, making it highly unlikely that this assay would lead to a signal with the brain form (cyp19a2) as a template. However, when screening various tissues for relative levels of expression, products were obtained readily also for the brain (Fig. 3). Sequencing of several of these products revealed perfect cyp19a1 sequences (data not shown), demonstrating the specificity of this assay, and at the same time confirming that the gonad form of aromatase is also expressed to a certain extent in the brain of fish (Kwon et al. 2001, Trant et al. 2001, Choi et al. 2005). Other tissues that express aromatase are the testis, and interestingly we also detected expression in the male gill. Although the relative level of expression was low for this tissue, the positive signal was consistently obtained in repeated runs.

\section{0ß-Hydroxysteroid dehydrogenase}

During the attempts to determine the sequence of a central part of cyp19a1, two widely different sequences were amplified from ovarian samples collected at different time points during sexual maturation. Whereas one showed to be a central part of Atlantic cod cyp19a1 as expected, the other one could be identified as a large part of 20ß-hsd. It can be speculated that this resulted from the presumably very high expression level of $20 \beta$-hsd in the respective sample, together with the degeneracy of the primers. There were only seven mismatches in the $30 \mathrm{nt}$ long forward primer when compared with the 200-hsd sequence, and only six in the $20 \mathrm{nt}$ long reverse primer, in the latter all of them in the $5^{\prime}$ part (data not shown). Nevertheless, this allowed us to design specific $5^{\prime}$ - and $3^{\prime}$ RACE primers and to amplify the $5^{\prime}$ and $3^{\prime}$ ends of the 20ß-hsd mRNA. After compiling consensus sequences from the overlapping fragments, primers were designed to amplify the whole presumptive coding regions in one single piece.

The full-length mRNA sequence for $20 \beta$-HSD had a length of 1232 nucleotides with an ORF of 825 nucleotides and $5^{\prime}$ and $3^{\prime}$ UTRs of 91 and 312 nucleotides respectively. In contrast to the cyp19a1 gene, the complete sequence of the $3^{\prime}$-UTR could be determined without difficulty. The $3^{\prime}$-UTR ended with a poly(A) sequence, 21 nucleotides downstream of a perfect AATAAA polyadenylation signal, although another such signal was located 69 nucleotides further upstream. The deduced amino acid sequence of 275 residues showed the highest similarity with carbonyl reductase like 20 $\beta$-HSD sequences from other fish species, ranging from $57 \cdot 1$ to $79 \cdot 6 \%$. The characteristic features like the Rossmann-fold responsible for NAPDH binding or the TyrXXXLys-motif crucial for catalytic activity were conserved in Atlantic cod, with the 

G. morhua
D. labrax
O. mykiss
D. rerio
I. punctatus
A. japonica

$1 \ldots \ldots 10 \ldots \ldots .20 \ldots \ldots . \ldots 30 \ldots \ldots 40 \ldots \ldots 60 \ldots \ldots 60 \ldots . \ldots 70 \ldots \ldots 0$ - -MDLFS - VCEWTVAPLRLDVLMVD - LGPRNATADTVA - - - - - - EVV - CVASRELLLLLLLLLLVAWTHRE - RATVPGP 67 - - MDLIS - ACERAMTPVGLDTIVAD - LVSTS PNATAVG - - - - - - - SPG - ISVATITLILLVCLLLVAWSHTD - KNTVPGP 67 - MDLLSPVCGRVMAVVCLDTVIADLLVSESRNATATR - - - - - - SEG- ISLATGSLLLLLCLLLAAWRHTD - NNSVPGP 69 MAGDLLQ - PCG - - MKPVRLGEAVVDLLIQRAHNGTERA - - - - - - MAAHVF P - MCERTRKPVHF SETVMEILLREARNGTDPR - - - - - - YENPRGIT - LLLLLCLVLLLTVWNRHEKKCSIPGP 71 - - - - - - - - - - - MKHLEEIVMEALMPASRNATQTAGRVVSGATAALLSGATAALLLLLCALLAAWSRSD - KSSVPGP 64

\section{Transmembrane helix}

$\ldots \ldots \ldots 90 \ldots \ldots 100 \ldots \ldots 110 \ldots \ldots 120 \ldots \ldots 130 \ldots \ldots 140 \ldots \ldots 150 \ldots \ldots 160$

YYCLGVGPLLCYLRFIWTGIGTASNYYNNKYGSMARVWINGEETLILSSSSTVRHVLRSAQYTSRFGSKQGLGCLGMDGR 147 SFCLGLGPLLSYLRFIWTGIGTASNYYNNKYGDIVRVWINGEETLILSRASVVHHVLKNGHYTSRFGSKQGLSCMGMYER 147 FFCLGVGPLLSYLRFIWTGIGTASNYYNSKYGDIVRVWINGEETFILSSSSAVHHVLRQGRYTSRFGSKQGLSCIGMDER 149 SFFFGLGPVVSYCRFIWSGIGTASNYYNSKYGDIVRVWINGEETLILSRSSAVYHVLRKSLYTSRFGSKLGLQCIGMHEQ 150 SFCLGLGPLMSYCRF IWMGIGTASNYYNEKYGDMVRVWISGEETLVLSRPSAVYHVLKHSQYTSRFGSKLGLQCIGMHEQ 151 PFYMGIGPLLSYFRFIWTGIGTASNYYNERYGDIVRVWINGEETIILSRSSAVYQVLRKPQYTSRFGSKQGLRCIGMHER 144

\section{G. morhua \\ D. labrax \\ O. mykiss \\ D. rerio \\ I. punctatus \\ A. japonica}
G. morhua
D. labrax
O. mykiss
D. rerio
I. punctatus
A. japonica

$\ldots \ldots 170 \ldots \ldots 180 \ldots \ldots 190 \ldots \ldots 200 \ldots \ldots 210 \ldots \ldots 220 \ldots \ldots 230 \ldots \ldots 240$

GIIFNNDVALWKKTRSYFARALTGPGVLQTVDVCTASTQSHLDSLRADHPSSGPGEDLRQVDVLSVLRGIVVDVSNTLFL 227 GIIFNNNVTLWKQIRNYFSKALTGPGLQQTVEVCVSSTQTHLDDLDKLD - . - . - . - - NVDVLSLLRCTVVDISNRLFL 217 GIIFNSNMALWKKTRTYFAKALTGPGLQKTVDVCVSSTQTHLDALQGPDGLMG - - - - - GQVDVLSLLRCTVVDISNRLFL 224 GIIFNSNVALWKKVRAFYAKALTGPGLQRTMEICTTSTNSHLDDLSQLTDAQG - - - - - - QLDILNLLRCIVVDVSNRLFL 224 GIIFNSNVTLWRKVRTYFAKALTGPGLQRTLEICTMSTNTHLDGLSRLTDAQG - - - - - - - HVDVLNLLRCIVVDISNRLFL 225 GIIFNNNIELWKKVRTYFAKALTGPGLQRTVAICVASTDSHLDQLEELTDLSG - - - - - - QVDILNLLRCTIVDISNQMFL 218

$\ldots \ldots 250 \ldots \ldots 260 \ldots \ldots 270 \ldots \ldots 280 \ldots \ldots 290 \ldots \ldots 300 \ldots \ldots 310 \ldots \ldots 20$ GVPVDEKDLLAKILKYFDTWQTVLIKPDLYFKLDWIHRRQKDAAQELQDAIEVLIDLKRRELQEADKLDRINFTADLIFA 307 GVPVNEKELLLKIQKYFDTWQTVLIKPDIYFKFDWIHQRHKTAAQELQDAIESLVEQKRRDMEQADKLD-INFTADLIFA 296 GVPLNEKELLQKIQKYFDTWQTVLIKPDVYFKLDWIHEKHRRAAQELEDAIESLVDQKRRGLQEADKLDHINFTADLIFA 304 GVPLNEHDLLQKIHKYFDTWQTVLIKPDVYFRLDWLHRKHKRDAQELQDAITALIEQKKVQLAHAEKLDHLDFTAELIFA 304 DVPLNEQNLLFKIHRYFETWQTVLIKPDFYFRLKWLHDKHRNAAQELHDAIEDLIEQKRTELQQAEKLDNLNFTEELIFA 305 RVPLNEKELLVKIQKYFEAWQTVLIRPDFLFKFEWMYKEHKEAAHELHEAMEILVEKKRKALEEAEKLDDADFATDLIFA 298

$\ldots \ldots 330 \ldots \ldots 340 \ldots \ldots 350 \ldots \ldots 360 \ldots \ldots 370 \ldots \ldots 38 \ldots \ldots 39 \ldots \ldots$

QGHGELSADHVRQCVLEMVIAGPDTLSVSLLFMLLLLKQHPEVELRILTEIDSVIGEGKLRNEDLPQLCVMENFINESLR 387 QNRGELTAENVRQCVLEMVIAAPDTLSVSLFFMLLLLKQNPDVELQLLQEIDTVVGERQLQNGDLQRLQVLESFVNECLR 376 QSHGELSAENVRQCVLEMVIAAPDTLSISLFFMLLLLKQNPDVELQLLEEIDTAIGDRELHNSDLQNLRVLESFINESLR 384 QSHGELSAENVRQCVLEMVIAAPDTLSISLFFMLLLLKQNPDVELKILQEMDSVLAGQSLQHSHLSKLQILESFINESLR 384 QSHGELTAENVRQCVLEMVIAAPDTLSISVFFMLLLLKQNAEVERRILTEIHTVLGDTELQHSHLSQLHVLECFINEALR 385 QNHGELSAENVQQCILEMIIAAPDTMSISLFFMLMLLKQNPEVEQEILKELDTVIGDKKAENSNLQHLIIMESFINESLR 378 $\begin{array}{ll}\text { I-helix Ozol's peptide } & \\ & \end{array}$

G. morhua

D. labrax

o. mykiss

D. rerio

I. punctatus

A. japonica

$\ldots \ldots 410 \ldots \ldots 420 \ldots \ldots 430 \ldots \ldots 440 \ldots \ldots 450 \ldots \ldots 460 \ldots \ldots 470 \ldots \ldots 480$ FHPVVDFTMRRALSDDVIDGYRVPKGTNVILNVGRMHRTEFYPKPNEFSLDNFEKSVPSRYFQPFGSGPRSCVGKHIAMV 467 FHPVVDFTMRRALSDDIIDGYRVPKGTNIILNTGHMHRTEFFLKPNEFNLDNFKKNPPRRYFQPFGSGPRACVGKHIAMV 456 FHPVVDFTMRRALSDDVISGYRVPKGTNIILNMGRMHRSEFFLKPNEF SLDNFEKNI PNRFFQPFGSGPRSCVGKHIAMV 464 FHPVVDFTMRRALDDDVIEGYNVKKGTNIILNVGRMHRSEFF SKPNQF SLDNFHKNVP SRFFQPFGSGPRSCVGKHIAMV 464 FHPVVDFSYRRALDDDVIEGFRVPRGTNIILNVGRMHRSEFYPKPADFSLDNFNKPVPSRFFQPFGSGPRSCVGKHIAMV 465 YHPVVDFTMRKSLEDDVIEGYKVFKGTNIILNVGRMHKCEFF SKPNEF SLENFEKTVPNRFFQPFGSGPRSCVGKHISMV 458 Aromatase-specific Heme-binding

\section{G. morhua \\ D. labrax \\ O. mykiss \\ D. rerio \\ I. punctatus \\ A. japonica}

$$
500 \ldots \ldots 510 \ldots \ldots 520 \ldots \ldots 530 \ldots \ldots 50 \ldots \ldots
$$

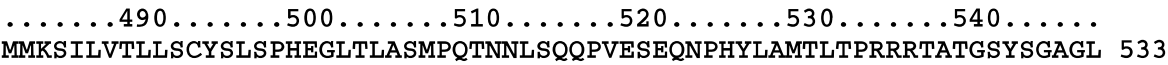
MMKSILVTLLSQYSVCPHKGLTLDCLPQTNNLSQQPVEHQQEAEHLSMRFLSRQRGSWKTL - - - - 518 MMKSILVTLLSRYSVCPHEGLTLDCLPQTNNLSQQPVE - - EEGEPHTMKFLPRHQARKQS - - - - - 523 MMKSILVALLSRFSVCPMKACTVENIPQTNNLSQQPVE - - EPSSLSV - . . . . . . . . . . . 510 MMKAVLLMVLSRF SVCPEESCTVENIAHTNDLSQQPVE - - -DKHTLSVRFI PRNTHTRNRKA - - - 525

MMKAILATLLSRYTMCPRDGRTLNNIRKTNNLSQQLAE - - KDSELTMMFTPRRRQ - - - - - - - - 512

Figure 1 ClustalX comparison of the deduced amino acid sequence of the Gadus Morhua P450 Aromatase (CYP19A1) open reading frame with a choice of teleost CYP19A1 sequences. Numbers to the right refer to the position of the amino acid. The predicted motifs of the transmembrane helix, the I-helix, the Ozol's peptide, the aromatase-specific region, and the heme-binding are shaded. Sequence information of Atlantic cod cyp19a1 can be viewed in the NCBI GenBank database with accession number DQ402370.

exception of a conservative alanine to serine change at position 2 of the Rossmann-fold (data not shown).

The same primers were then applied on genomic DNA in order to determine the exact locations of introns.
Despite several attempts, the sequence of the corresponding genomic locus of the coding sequence of $20 \beta$-hsd could not be amplified in one piece, but rather had to be assembled from two overlapping fragments. 


\begin{tabular}{|c|c|c|c|c|c|c|c|c|c|c|c|c|c|}
\hline \multirow[t]{2}{*}{ Gene } & \multicolumn{2}{|c|}{$5^{\prime}$ exon } & \multicolumn{8}{|c|}{ Intron } & \multicolumn{2}{|c|}{$3^{\prime}$ exon } & Intron length \\
\hline & -2 & -1 & +1 & +2 & +3 & +4 & & -3 & -2 & -1 & +1 & +2 & \\
\hline \multirow[t]{5}{*}{$20 \beta-h s d$} & A & $\mathrm{T}$ & G & $\mathrm{T}$ & $\mathrm{A}$ & G & $\ldots$ & $\mathrm{T}$ & A & G & $\mathrm{T}$ & G & 515 \\
\hline & $\mathrm{A}$ & G & G & $\mathrm{T}$ & A & $\mathrm{C}$ & $\ldots$ & $\mathrm{T}$ & A & $\mathrm{G}$ & A & A & 674 \\
\hline & A & G & G & $\mathrm{T}$ & A & C & $\ldots$ & C & A & G & G & $\mathrm{T}$ & 92 \\
\hline & C & $\mathrm{T}$ & G & $\mathrm{T}$ & A & A & $\ldots$ & C & A & G & G & C & $>616$ \\
\hline & $\mathrm{A}$ & G & G & $\mathrm{T}$ & $\mathrm{C}$ & A & $\ldots$ & $\mathrm{T}$ & $A$ & G & $\mathrm{A}$ & $\mathrm{T}$ & 175 \\
\hline \multirow[t]{8}{*}{ cyp19a1 } & $A$ & G & G & $\mathrm{T}$ & C & A & $\ldots$ & C & A & G & G & $\mathrm{C}$ & 233 \\
\hline & A & G & G & $\mathrm{T}$ & $\mathrm{C}$ & $\mathrm{T}$ & $\ldots$ & $\mathrm{C}$ & A & G & $\mathrm{C}$ & $\mathrm{T}$ & 160 \\
\hline & A & G & G & $\mathrm{T}$ & G & $\mathrm{C}$ & $\ldots$ & $\mathrm{T}$ & A & G & C & $\mathrm{T}$ & 170 \\
\hline & $\mathrm{T}$ & G & G & $\mathrm{T}$ & $\mathrm{A}$ & $\mathrm{T}$ & $\ldots$ & $\mathrm{C}$ & A & G & $\mathrm{A}$ & G & 197 \\
\hline & G & C & G & $\mathrm{T}$ & G & G & $\ldots$ & $\mathrm{C}$ & A & G & $\mathrm{T}$ & $\mathrm{C}$ & 145 \\
\hline & A & G & G & $\mathrm{T}$ & $\mathrm{A}$ & $\mathrm{A}$ & $\ldots$ & $\mathrm{C}$ & $\mathrm{A}$ & G & G & G & 412 \\
\hline & A & G & G & $\mathrm{T}$ & $\mathrm{A}$ & A & $\ldots$ & A & $\mathrm{A}$ & G & G & $\mathrm{C}$ & 365 \\
\hline & G & C & G & $\mathrm{T}$ & $\mathrm{A}$ & A & $\ldots$ & $\mathrm{C}$ & A & G & G & $\mathrm{T}$ & 591 \\
\hline \multirow[t]{6}{*}{$\operatorname{eef} 1 \alpha$} & $\mathrm{A}$ & G & G & $\mathrm{T}$ & A & A & $\ldots$ & $\mathrm{C}$ & A & G & $\mathrm{A}$ & $\mathrm{T}$ & 306 \\
\hline & A & G & G & $\mathrm{T}$ & G & A & $\ldots$ & $\mathrm{C}$ & A & G & G & $\mathrm{C}$ & 109 \\
\hline & A & G & G & $\mathrm{T}$ & G & A & $\ldots$ & $\mathrm{T}$ & A & G & A & $\mathrm{T}$ & 109 \\
\hline & C & G & G & $\mathrm{T}$ & G & $A$ & $\ldots$ & $\mathrm{C}$ & A & G & G & $\mathrm{T}$ & 110 \\
\hline & A & G & G & $\mathrm{T}$ & G & $\mathrm{A}$ & $\ldots$ & $\mathrm{C}$ & A & G & G & $\mathrm{T}$ & 107 \\
\hline & $\mathrm{C}$ & G & G & $\mathrm{T}$ & $\mathrm{A}$ & A & $\ldots$ & $\mathrm{C}$ & A & G & G & $\mathrm{T}$ & 118 \\
\hline Consensus & A & G & $\underline{G}$ & $\underline{T}$ & A & A & & $\mathrm{C}$ & $\underline{\mathrm{A}}$ & $\underline{\mathbf{G}}$ & G & $\mathrm{T}$ & \\
\hline Frequency (\%) & 68 & 79 & 100 & 100 & 53 & 63 & & 68 & 100 & 100 & 53 & 53 & \\
\hline
\end{tabular}

Figure 2 Intron boundaries. Nucleotide sequences around the determined intron sites are shown for each of the three genes. Their frequency or degree of conservation for each position is indicated at the bottom. Sequence information of Atlantic cod $20 \beta$-hsd and eef $1 \alpha$ can be viewed in the NCBI GenBank database with accession numbers DQ402369 and DQ402371 respectively.

Nevertheless, the intron positions could be identified, and the length of the five introns ranged from 92 nucleotides for intron 3 to 674 nucleotides for intron 2 (Fig. 2). The only partially sequenced intron 4 was at least 600 nucleotides long, but might well be in the range of intron 2. The total length of sequence of the corresponding genomic locus of the coding sequence was slightly more than $3 \mathrm{~kb}$, starting with the ATG and ending with the stop codon of the coding sequence.

Based on the determined exon-exon boundaries, an mRNA-specific TaqMan assay was developed also for $20 \beta-h s d$. Screening of various tissues for relative levels of expression showed that $20 \beta$-hsd is almost ubiquitously expressed, with the highest relative expression found in ovary and brain, and the lowest in intestine and muscle. There were no big differences between male and female tissues, with the exception of heart and gill, and of course the gonad, where the expression in the testis is very low when compared with that in the ovary.

\section{Eukaryotic elongation factor $1 \alpha(E E F 1 \alpha)$}

The mRNA sequence for EEF1 $\alpha$ consisted of 1502 nucleotides including a $5^{\prime}$-UTR of 54 nucleotides and an incomplete $3^{\prime}$-UTR of 62 nucleotides. When this sequence was blasted against an expressed sequence tag library generated in this laboratory, additional 237 nucleotides of the 3'-UTR were identified, making up a total of 1739 nucleotides for the mRNA. The ORF of 1386 nucleotide codes for a deduced protein of 461 amino acids, and the similarity scores to EEF $1 \alpha$ protein sequences from other fish species was $86 \cdot 1-91 \cdot 2 \%$ (data not shown). The sequence for the corresponding genomic locus including six introns encompassed 2245 nucleotides, and the intron lengths ranged from 109 to 118 for introns 2 to 6 , whereas the first intron was 306 nucleotides long.

\section{RNA quality and seasonal changes in gene expression}

When starting to extract tissue samples from different time points during an annual cycle, huge differences concerning RNA quality and quantity were observed (data not shown). Intact $28 \mathrm{~S}$ and $18 \mathrm{~S}$ rRNA peaks that are used by the software to assign an RNA integrity number (RIN value) to the samples were dwarfed by high amounts of one or several small RNA(s) in those samples collected in summer, when the gonads are still small and just start to grow. A slight change in the extraction method, from isopropanol precipitation to column purification, enabled us to get more homogenous capillary electrophoresis profiles and more similar RNA amounts throughout a seasonal 


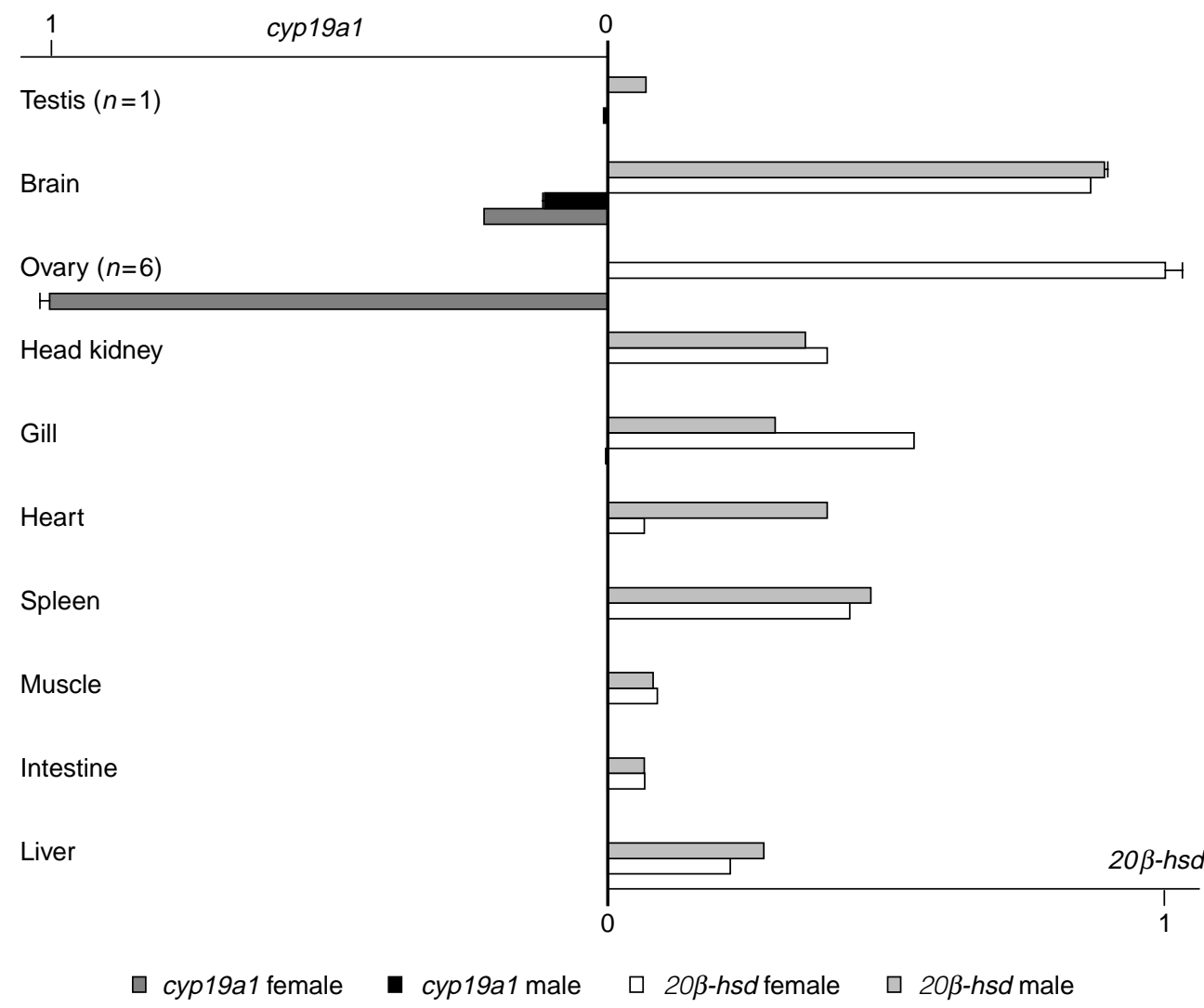

Figure 3 Relative expression of cyp19a1 (left side of the figure) and 20 - -hsd mRNA (right side of the figure) respectively in adult Atlantic cod tissue as determined by real-time quantitative RT-PCR. Designing assay with either probe or one of the primers spanning an exon-exon boundary ensures that the signal exclusively comes from mRNA. Expression in the ovary was set to 1 . Where not stated otherwise, one organ from each gender was analyzed $(n=1)$ except brain, where two female and one male brain samples were analyzed. Error bars are indicated where appropriate.

cycle. Ovarian samples collected from different time points during 1 year were analyzed for all four genes by q-RT-PCR, including the 18S rRNA that was chosen as an alternative standard or reference gene. Both genes showed some seasonal variation, with less fluctuation for $18 \mathrm{~S}$ than for eefl $\alpha$ (Fig. 4). In order to gather more statistically relevant data, six samples from January to July 2005 were analyzed. The average $C_{\mathrm{t}}$ values for $18 \mathrm{~S}$ were 10.50 in January and $11 \cdot 35$ in July, with an S.D. of $0 \cdot 19$ and 0.37 respectively. For the eefl $\alpha$ gene, the corresponding values were $21 \cdot 73(0 \cdot 72)$ and $19 \cdot 80(0 \cdot 81)$. This is in good agreement with the data obtained when running only one or two samples per month over a 9-month period. It indicates that both reference genes are sub-optimal, with 18S RNA being more stably expressed in this organ than eefl $\alpha$ mRNA. Aromatase and 20ß-hsd showed much higher variation between the data for January and those for July, with an upregulation of cyp19a1 transcripts, and a downregulation of 20ß-hsd mRNA during the same period. At the same time, very low expression levels were observed in a testis sample from October that was run for comparison.

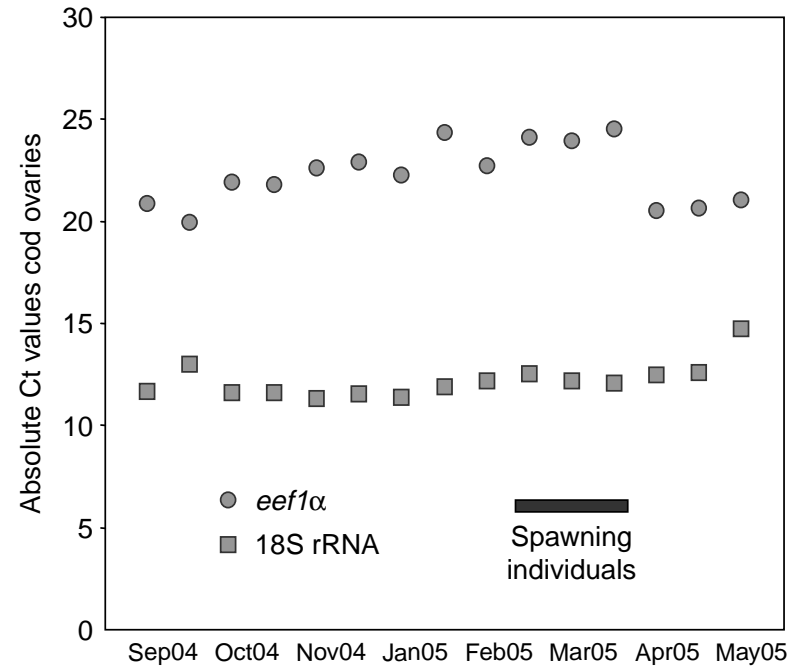

Figure 4 Absolute threshold cycle $\left(C_{t}\right)$ values for the reference genes eef $1 \alpha$ and $18 \mathrm{~S}$ rRNA respectively to show the seasonal variation observed for samples taken from cod ovaries. The spawning season is indicated by a black bar. 


\section{Discussion}

Aromatase is a key player in the enzymatic complex converting androgens (C19 steroids) to estrogens (C18 steroids). In mammals, only one cyp19 gene exists, and tissue specificity and developmental expression patterns are generated by differential use of promoters. Teleosts, however, have two cytochrome P450 aromatase genes, probably generated by gene duplication during evolution (Chiang et al. 2001). The form primarily expressed in the ovary is designated cyp19a1, while the form predominantly expressed in the brain is termed cyp19a2. Since the expression level of at least its ovarian form mRNA correlates well with the enzymatic activity (Fukada $e t$ al. 1996), measurements of mRNA expression levels have been used as indicators of estrogen production capacity. For the first time, a complete cyp 19a1 sequence for Atlantic cod has been determined. The cyp19a1 sequence assembled in this study contains all the typical features of an aromatase gene and was unambiguously assigned to the cyp19a1 cluster of aromatase sequences (data not shown), distant from numerous fish cyp19a2 sequences. However, the similarity to other fish cyp19a1 sequences is surprisingly low (56.2-68.9\% on the deduced amino acid level). Typically similarities between ovarian forms of teleost aromatases are at least $62 \%$, often they reach more than $80 \%$ with the closest sequence. In the case of the two closely related tilapias (Oreochromis niloticus and O. mossambicus), it is even as high as $97 \%$. Nevertheless, a partial cyp19a1 sequence derived from Atlantic cod ovary has been deposited in GenBank (accession number AJ555405) and showed $99.7 \%$ identity to our sequence on the nucleotide level, demonstrating that this indeed represents the mRNA sequence for the ovarian form of aromatase in Atlantic cod. Together with the partial cyp19a2 sequence also showing only low similarity scores to other fish cyp 19a2sequences $(65 \cdot 1-80 \cdot 1 \%$ on the deduced amino acid level), this indicates that the highly evolved gadoids have sequences very diverse from other fishes.

Since the ovarian form of aromatase is expressed to a certain extent also in the brain (and vice versa; Kwon et al. 2001, Trant et al. 2001, Choi et al. 2005), the nature of the positive signals obtained when running a screen of tissues including brain and gill was investigated. Surprisingly, low but consistently positive signals were obtained when running a male gill sample. While no expression of gonadal aromatase in gills of sea bass could be detected by a conventional RT-PCR (Blázquez \& Pifferer 2004), expression of both cyp19 genes was detected in the gills of rainbow trout (Dalla Valle $e t a l$. 2002) and orange-spotted grouper (Zhang et al. 2004) by Southern blotting of RT-PCR products. Low levels of cyp19 mRNA were detected also in gills of southern flounder (Luckenbach et al. 2005), adding to the growing evidence that fish express aromatase locally in gills. However, it is not clear what function, if any, aromatase might serve in this tissue or why it should be preferentially expressed in male cod. One might speculate that there is a need for certain levels of estradiol in this tissue, and in male fish this can only be produced locally by conversion from testosterone, mediated by locally expressed aromatase. In contrast, female fish have estradiol in the circulation, thereby contributing to the presence of certain levels of this steroid hormone even in the gills.

Sequencing of the products obtained by analyzing brain samples confirmed that the amplified target indeed was derived from the cyp19a1 gene and ruled out possible cross-reactivity with the brain form. Comparison with the partial cyp19a2 sequence also determined in this study (data not shown) revealed a conclusive number of differences. In addition, the primers and probes designed for this quantitative realtime PCR are highly unlikely to lead to a positive amplification signal for cyp19a2. We are therefore convinced that this assay represents a highly specific tool for the assessment of expression of the gonadal form of cytochrome P450 aromatase in Atlantic cod. To our knowledge, this is only the second time that such a highly specific and sensitive quantitative real-time PCR has been reported for a $c y p 19$ gene of a batch spawner. In Atlantic halibut (Matsuoka et al. 2006), expression of both cyp19 isoforms was examined in juveniles in order to investigate sex differentiation. It remains to be seen if such an assay will be useful in studies on the regulation of vitellogenesis and final oocyte maturation in periodic spawners, such as cod and halibut.

The 20ß-hsd sequence also showed only moderate similarity scores with other fish 20ß-hsd sequences (57.1-79.6\% on the deduced amino acid level), further confirming the evolutionary distant sequences of Atlantic cod. On the other hand, the features typical for carbonyl reductase like 20 $\beta$-HSD were conserved in Atlantic cod, strongly suggesting that the sequence determined in this study indeed represents the 20ß-hsd gene of Atlantic cod. In agreement with the data obtained for rainbow trout (Guan et al. 1999) and Nile tilapia (Senthilkumaran et al. 2002), 20ß-hsd was quite ubiquitously expressed. However, there seemed to be a sex-specific variation in 20ß-hsd expression in heart and gills in Atlantic cod, in addition to the expected large differences in the gonads. Since none of the previous studies has looked at samples from both sexes, the significance of these findings needs to be further investigated. In conclusion, we are convinced that this assay is a similarly specific and sensitive tool for the assessment of 20ß-hsd mRNA expression as the aromatase assay.

In search of a reference gene for quantification of mRNA expression by the $\Delta \Delta C_{\mathrm{t}}$ method (Bustin 2000), we tested a number of genes either used in many studies (18S rRNA, $\beta$-actin) or suggested by previous experience in our institute (eef1 $\alpha$ ) (Frost \& Nilsen 2003). 
However, when carefully tested none of the genes fulfilled the stability criteria, all showed at least some seasonal variation in ovarian samples (Fig. 4 and data not shown), despite careful quantification of the RNA used for cDNA synthesis. One explanation for the large variation seen when running eefl $\alpha$ and to a certain extent also 18S rRNA, is the asynchronous synthesis and storage of ribosomal components during oocyte growth (le Maire \& Denis 1987, Thiry \& Poncin 2005). The initial RNA extraction method using isopropanol precipitation of total RNA produced unexpected capillary electrophoresis profiles when ovarian samples from June to July were extracted. High peaks in the range of about 100 nucleotides completely dwarfed the normally predominant $18 \mathrm{~S}$ and $28 \mathrm{~S}$ rRNA peaks characteristic of intact total RNA. A similar phenomenon was observed in early studies of Xenopus oocytes where first $5 \mathrm{~S}$ rRNA and to a certain extent also protein components of the ribosomes were synthesized before a switch occurred to $18 \mathrm{~S}$ and 28S RNA production later in oogenesis (Scheer et al. 1976). A simple change in the extraction method from isopropanol precipitation to column purification removed the large peaks of presumably 5S rRNA and tRNA, but the seasonal trend in eefl $\alpha$ remained (Fig. 4). It was therefore concluded that for future studies, when long-term series may be analyzed, instead of reference genes the input amount of RNA used for cDNA synthesis should be carefully standardized (Campbell et al. 2006).

In conclusion, we have determined the mRNA and genomic sequence of two key genes involved in oogenesis and final oocyte maturation. Sensitive mRNA-specific quantitative real-time PCR assays were established and evaluated for these genes as well as for EEF1 $\alpha$. Testing of several candidate reference genes did not give satisfactory results, and careful standardization of input RNA was chosen for relative quantification of gene expression.

\section{Acknowledgements}

The authors wish to thank Rita Karlsen for excellent technical assistance. The study was financed by the Research Council of Norway, project no. 139630. The authors declare that there is no conflict of interest that would prejudice the impartiality of this scientific work.

\section{References}

Blázquez M \& Piferrer F 2004 Cloning, sequence analysis, tissue distribution, and sex-specific expression of the neural form of $\mathrm{P} 450$ aromatase in juvenile sea bass (Dicentrarchus labrax). Molecular and Cellular Endocrinology 219 83-94.

Bustin SA 2000 Absolute quantification of mRNA using real-time reverse transcription polymerase chain reaction assays. Journal of Molecular Endocrinology 25 169-193.
Campbell B, Dickey J, Beckman B, Young G, Pierce A, Fukada H \& Swanson P 2006 Previtellogenic oocyte growth in salmon: relationships among body growth, plasma insulin-like growth factor1, estradiol-17beta, follicle-stimulating hormone and expression of ovarian genes for insulin-like growth factors, steroidogenic-acute regulatory protein and receptors for gonadotropins, growth hormone, and somatolactin. Biology of Reproduction 75 34-44.

Chang XT, Kobayashi T, Kajiura H, Nakamura M \& Nagahama Y 1997 Isolation and characterization of the cDNA encoding the tilapia (Oreochromis niloticus) cytochrome $\mathrm{P} 450$ aromatase (P450arom): changes in P450arom mRNA, protein and enzyme activity in ovarian follicles during oogenesis. Journal of Molecular Endocrinology 18 $57-66$.

Chiang EF, Yan YL, Guiguen Y, Postlethwait J \& Chung BC 2001 Two Cyp19 (P450 aromatase) genes on duplicated zebrafish chromosomes are expressed in ovary or brain. Molecular Biology and Evolution 18 542-550.

Choi JY, Park JG, Jeong HB, Lee YD, Takemura A \& Kim SJ 2005 Molecular cloning of cytochrome $\mathrm{P} 450$ aromatases in the protogynous wrasse, Halichoeres tenuispinis. Comparative Biochemistry and Physiology. Part B, Biochemistry and Molecular Biology 141 49-59.

Dalla Valle L, Lunardi L, Colombo L \& Belvedere P 2002 European sea bass (Dicentrarchus labrax L.) cytochrome P450arom: cDNA cloning, expression and genomic organization. Journal of Steroid Biochemistry and Molecular Biology 80 25-34.

Frost P \& Nilsen F 2003 Validation of reference genes for transcription profiling in the salmon louse, Lepeophtheirus salmonis, by quantitative real-time PCR. Veterinary Parasitology 118 169-174.

Fukada S, Tanaka M, Matsuyama M, Kobayashi D \& Nagahama Y 1996 Isolation, characterization, and expression of cDNAs encoding the medaka (Oryzias latipes) ovarian follicle cytochrome P-450 aromatase. Molecular Reproduction and Development 45 285-290.

Gen K, Okuzawa K, Kumakura N, Yamaguchi S \& Kagawa H 2001 Correlation between messenger RNA expression of cytochrome P450 aromatase and its enzyme activity during oocyte development in the red seabream (Pagrus major). Biology of Reproduction $\mathbf{6 5}$ $1186-1194$

Goetz FW, McCauley L, Goetz GW \& Norberg B 2006 Using global genome approaches to address problems in cod mariculture. ICES Journal of Marine Science 63 393-399.

Guan G, Tanaka M, Todo T, Young G, Yoshikuni M \& Nagahama Y 1999 Cloning and expression of two carbonyl reductase-like 20betahydroxysteroid dehydrogenase cDNAs in ovarian follicles of rainbow trout (Oncorhynchus mykiss). Biochemical and Biophysical Research Communications 255 123-128.

Jörnvall H, Persson B, Krook M, Atrian S, Gonzalez-Duarte R, Jeffery J \& Ghosh D 1995 Short-chain dehydrogenases/reductases (SDR). Biochemistry 34 6003-6013.

Kjesbu OS 1989 The spawning activity of cod, Gadus morhua L. Journal of Fish Biology 34 195-206.

Kjesbu OS 1994 Time of start of spawning in Atlantic cod (Gadus morhua) females in relation to vitellogenic oocyte diameter, temperature, fish length and condition. Journal of Fish Biology 45 719-735.

Kjesbu OS, Klungsoyr J, Kryvi H, Witthames PR \& Walker MG 1991 Fecundity, atresia, and egg size of captive Atlantic cod (Gadus morhua) in relation to proximate body-composition. Canadian Journal of Fisheries and Aquatic Sciences 48 2333-2343.

Kjesbu OS, Kryvi H \& Norberg B 1996 Oocyte size and structure in relation to blood plasma steroid hormones in individually monitored, spawning Atlantic cod. Journal of Fish Biology 49 $1197-1215$

Kwon JY, McAndrew BJ \& Penman DJ 2001 Cloning of brain aromatase gene and expression of brain and ovarian aromatase genes during sexual differentiation in genetic male and female Nile tilapia Oreochromis niloticus. Molecular Reproduction and Development $\mathbf{5 9}$ 359-370. 
Luckenbach JA, Early LW, Rowe AH, Borski RJ, Daniels HV \& Godwin J 2005 Aromatase cytochrome P450: cloning, intron variation, and ontogeny of gene expression in southern flounder (Paralichthys lethostigma). Journal of Experimental Zoology. Part A, Comparative Experimental Biology 303 643-656.

le Maire M \& Denis H 1987 Biochemical research on oogenesis. Binding of tRNA to the nucleoprotein particles of Xenopus laevis previtellogenic oocytes. Journal of Biological Chemistry 262 654-659.

Matsuoka MP, van Nes S, Andersen O, Benfey TJ \& Reith M 2006 Realtime PCR analysis of ovary- and brain-type aromatase gene expression during Atlantic halibut (Hippoglossus hippoglossus) development. Comparative Biochemistry and Physiology. Part B, Biochemistry and Molecular Biology 144 128-135.

Øiestad V, Kvenseth PG \& Folkvord A 1985 Mass-production of Atlantic cod juveniles Gadus morhua in a Norwegian saltwater pond. Transactions of the American Fisheries Society 114 590-595.

Olsvik PA, Lie KK, Jordal AE, Nilsen TO \& Hordvik I 2005 Evaluation of potential reference genes in real-time RT-PCR studies of Atlantic salmon. BMC Molecular Biology 6 1-9.

Scheer U, Trendelenburg MF \& Franke WW 1976 Regulation of transcription of genes of ribosomal RNA during amphibian oogenesis. A biochemical and morphological study. Journal of Cell Biology 69 465-489.

Senthilkumaran B, Sudhakumari CC, Chang XT, Kobayashi T, Oba Y, Guan G, Yoshiura Y, Yoshikuni M \& Nagahama Y 2002 Ovarian carbonyl reductase-like 20beta-hydroxysteroid dehydrogenase shows distinct surge in messenger RNA expression during natural and gonadotropin-induced meiotic maturation in Nile tilapia. Biology of Reproduction 67 1080-1086.

Senthilkumaran B, Yoshikuni M \& Nagahama Y 2004 A shift in steroidogenesis occurring in ovarian follicles prior to oocyte maturation. Molecular and Cellular Endocrinology 215 11-18.
Simpson ER, Mahendroo MS, Means GD, Kilgore MW, Hinshelwood MM, Graham-Lorence S, Amarneh B, Ito Y, Fisher CR, Michael MD et al. 1994 Aromatase cytochrome P450, the enzyme responsible for estrogen biosynthesis. Endocrine Reviews 15 342-355.

Tanaka M, Nakajin S, Kobayashi D, Fukada S, Guan G, Todo T, Senthilkumaran B \& Nagahama Y 2002 Teleost ovarian carbonyl reductase-like 20ß-hydroxysteroid dehydrogenase: potential role in the production of maturation-inducing hormone during final oocyte maturation. Biology of Reproduction 66 1498-1504.

Thiry M \& Poncin P 2005 Morphological changes of the nucleolus during oogenesis in oviparous teleost fish, Barbus barbus (L.). Journal of Structural Biology 152 1-13.

Trant JM, Gavasso S, Ackers J, Chung BC \& Place AR 2001 Developmental expression of cytochrome $\mathrm{P} 450$ aromatase genes (CYP19a and CYP19b) in zebrafish fry (Danio rerio). Journal of Experimental Zoology 290 475-483.

Van Nes S, Moe M \& Andersen Ø 2005 Molecular characterization and expression of two cyp19 (P450 aromatase) genes in embryos, larvae, and adults of Atlantic halibut (Hippoglossus hippoglossus). Molecular Reproduction and Development 72 437-449.

Wang Y \& Ge W 2002 Cloning of zebrafish ovarian carbonyl reductaselike $20 \beta$-hydroxysteroid dehydrogenase and characterization of its spatial and temporal expression. General and Comparative Endocrinology 127 209-216.

Zhang Y, Zhang W, Zhang L, Zhu T, Tian J, Li X \& Lin H 2004 Two distinct cytochrome $\mathrm{P} 450$ aromatases in the orange-spotted grouper (Epinephelus coioides): cDNA cloning and differential mRNA expression. Journal of Steroid Biochemistry and Molecular Biology 92 39-50.

Received in final form 15 August 2007

Accepted 29 August 2007

Made available online as an Accepted Preprint 31 August 2007 